\title{
On Iconicity in Chinese
}

\author{
GAO Wencheng, YE Tianyi \\ University of Shanghai for Science and Technology, Shanghai, China
}

\begin{abstract}
Iconicity principle provides a new framework for linguists to reexamine the relationship between the signifier and the signified. Apart from arbitrariness, iconicity principle also turns out to be true to some extent between form and meaning of linguistic symbols. This paper elaborates the iconicity principle in Chinese-mainly the sequencing iconicity, quantitative iconicity, symmetric iconicity, and asymmetric iconicity.
\end{abstract}

Keywords: cognitive linguistics, iconicity principle, Chinese

\section{Introduction}

The debate over arbitrariness and iconicity has existed in the field of philosophy and linguistics for centuries. Saussure (1916), the founder of modern linguistics, proposes the arbitrariness of linguistic symbols in his book Course in General Linguistics. He states that the relation between the signifier and the signified is arbitrary and their combination to form a linguistic symbol is conventional. However, under the framework of cognitive linguistics, it is maintained that language is formed on the basis of people's interactive experience and cognitive processing. Language expression is thus iconic to people's cognitive style, and under the influence of cognition, the language expression is also iconic to the objective world in a certain way and to a certain extent (Wang, 2009). In other words, iconicity indicates that the relation between linguistic form and signified content, including experiential structure, conceptual frames, and semantic system, is not arbitrary but motivated.

At present, there still lack sufficient researches that specifically focus on iconicity in Chinese. This paper attempts to analyze the iconicity principle in Chinese based on illustrations in a systematic and comprehensive way.

\section{Literature Review}

After the principle of arbitrariness dominates the linguistic field for a century, some foreign linguists begin to defy Saussure's theory and put forward the idea of iconicity.

Haiman (1985) divides the iconicity of language structure into isomorphism and motivation. The former refers to the iconicity of syntactic components and human experiential elements, that is, the correspondence between the form and meaning of a language structure. The latter demonstrates that the relation among different syntactic components is coherent to that among different human experiential elements.

Funding: This study is funded by the planning Fund of Humanities and Social Sciences from Ministry of Education of China (NO. 17YJA740012), From a Cognitive Perspective: A Contrastive Study of Existential Sentences in English and Chinese Based on Corpus.

GAO Wencheng, Ph.D., professor, College of Foreign Languages, University of Shanghai for Science and Technology, Shanghai, China.

YE Tianyi, undergraduate, College of Foreign Languages, University of Shanghai for Science and Technology, Shanghai, China. 
Givon (1989) maintains that there exists persuasive iconicity in human languages. He (1994) proposes sequential order principle and divides it into linear semantic principle and linear pragmatic principle. According to the principle, comparatively important information or information that is hard to obtain and predict usually appears first in the linear sequence. Halliday (Halliday \& Matthiessen, 1999) emphasizes his view that the relationship between meaning and form is not arbitrary but motivated in the book Construing Experience Through Meaning.

In the past decades, Chinese scholars also paid much attention to the study of iconicity and developed some relatively mature theories. Xu Guozhang (1988) believes that language is in essence a symbol system. Within this system, the relationship between different symbols is not arbitrary. Tai James (1988) suggests that since there is no inflection in Chinese, and its grammatical category is vague, it can be considered that Chinese grammar refers to principles in conceptual domain more to the grammatical rules of syntactic and morphological categories. Shen Jiaxuan (1993) has challenged arbitrariness and upheld iconicity. He maintains that under the influence of iconicity, language structure directly maps people's conceptual structure but not merely reveals about it. That is to say, the relationship between the signifier and signified is motivated. He has concluded distance iconicity, sequential iconicity, and quantitative iconicity in syntax. Hu Zhuanglin (1996) also states that the trend of iconicity of linguistic symbols is inevitable.

Wang Yin (1999) defines iconicity as the mapping relationship between linguistic signs and their signified in sound, form, or structure. He also summarizes current researches on iconicity from the following three aspects: phonetic aspect (e.g., onomatopoeia), morphological aspect (e.g., pictograph), and structural aspect (e.g., iconicity of syntactic structure). Additionally, he complements Shen's work and further proposes marked iconicity, topic iconicity, sentence iconicity, textual iconicity, and filtration iconicity. According to Wang Yin (1990), there is a high degree of iconicity between word order and time sequence in Chinese. Zhu Yongsheng (2002), however, holds that iconicity does exist at the level of compound words, derivatives, and syntax, but arbitrariness is still an unshakable principle for a single linguistic symbol. Hence, iconicity principle should be regarded as a supplement to Saussure's theory rather than a substitute for arbitrariness principle. He believes that the relationship between iconicity and arbitrariness is co-existence and even interactive.

Zhang Zhe (2004) concludes that iconicity occurs in dynamic process of language function, which is a significant extension. In her study about researches on iconicity of language in China (Zhang, 2007), she points out that researches about quantitative iconicity, symmetric iconicity, asymmetric iconicity are still relatively rare in China.

\section{The Iconicity Principle in the Chinese Language}

\section{Sequencing Iconicity}

Sequencing iconicity indicates that the order of language units in a language structure corresponds to the order of thinking (Wang, 1999, p. 6). As Shen (1993) puts it, the arrangement order of syntactic components maps the actual state or the sequence of events that they delineate. In other words, the temporal sequence of events or the temporal sequence of concepts is consistent with the linear expression of a linguistic description (Zhao, 2000). As for compound sentences, causative clauses and conditional clauses are placed before the main clause in most cases owing to sequencing iconicity, because it is generally considered that the cause comes first with the result coming second, and conditions should appear prior to actions. For example:

(1) Tā păo dào wū lǐ, duǒ le qũ lái. 
He run to house hide LE stand up.

"He ran into the house and hid himself."

In Sentence (1), the order of words is perfectly consistent with the order of events happened - the man first ran into the house and then hid himself. To change the order of the sentence would lead to semantic contradiction, rendering the whole sentence logically unreasonable, because by no means can a person hide in the house before he is actually in the house.

(2) Xiăo míng pá shàng yáng tái dă kāi chuāng hù rēng chū le shǒu zhōng de píng zǐ.

Xiao Ming climb balcony open window throw out hand DE bottle.

"Xiao Ming climbed up the balcony, opened the window and threw out the bottle in his hand."

Sentence (2) is of the same case. It describes three consecutive actions by Xiao Ming through the linear sequence of three verbs. Likewise, the alteration of any linguistic unit would make the sentence semantically wrong as it runs contrary to people's cognition towards the sequence of the whole event. No matter how many predicate verbs a sentence contains, the order of their arrangement would always be congruous to the order of the actual happening.

(3)

a. Tā zuò dì tiě dào zhè ér.

He take metro get here.

"He got here by metro."

b. Tā dào zhè ér zuò dì tiè.

He get here take metro.

"He came here to take the metro."

Sentence (3) is a pair of more evident examples. The discrepancy between Sentence (a) and Sentence (b) lies in the different positions of verbs. In the Sentence (a), "zuò (take)" appears prior to "dào (get)", and thus it describes a person first takes the metro and then arrives at a destination. However, in the Sentence (b), "dào (get)" is placed before "zuò (take)". Consequently, the sequence of actual happening the sentence depicts is that a person reaches a certain place first and then takes the metro there, probably because that place is near to the metro station. Even though Sentences (a) and (b) look much alike in form, the different order of words actually represents different events in Chinese.

(4) Méi yǒu shǔ̌, jiù méi yǒu shēng mìng.

Not have water then not have life.

"Without water, there would be no life."

Sentence (4) is a representative of complex sentence of supposition, with the structure of "méi yǒu ... jiù méi yǒu ... (Without ..., then there would be no...)". In the sentence, the conditional clause appears before the main clause. According to human's perception or understanding of the objective world, a premise comes prior to the deduction as the latter should be made based on the former. Therefore, it can be suggested that sequencing iconicity also applies to compound sentences in Chinese.

Generally speaking, sequencing iconicity reveals that the sequence of linguistic components is congruous to the sequence of the events happened or people's cognitive process. In Chinese, sequencing iconicity is reflected in the order of words within a single sentence as well as in the order of a subordinate clause and a main sentence in a complex sentence. 


\section{Quantitative Iconicity}

According to Shen (1993), to convey information that contains abundant messages, it is important to the speaker, and it is difficult for the listener to predict, since the sentence tends to possess many syntactic components and the language expressions tend to possess complex forms. Lin (1995) mentions that quantitative iconicity is also embodied in words and morphemes. He states that the more the number of forms is, the richer its meaning is. Wang (1999) provides a brief definition to quantitative iconicity that the number of linguistic units is in direct proportion to the quantity and complexity of the concepts represented, and in reversed proportion to the concepts' measurability. To put it simple, quantitative iconicity reveals that the more complex, important, and unpredictable the concept is, the more language signs are needed to describe it. In Chinese, quantitative iconicity is quite evident. Here are some instances. For instance:

(5)

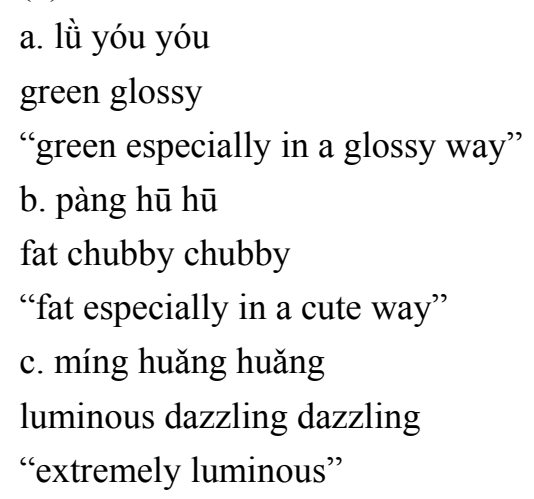

Example (5) represents a peculiar type of words in Chinese called "ABB-pattern words", which means words with the same second and third characters. Instances (a), (b), and (c) are all "ABB-patterned adjectives". Sentence (a) generally serves as the marker, indicating the distinctive characteristics that the adjective represents, while (b) mainly makes the word more vivid in terms of emotion, image, and style (Tang, 2004). Specifically speaking, when (a) "lǜ yóu yóu" is used to describe a bird's feather, the speaker implies that the feather is so green that it looks glossy and shiny. Likewise, when speaker uses (b) "pàng hū hū" to depict the image of a young boy, he actually adds his personal affection into the description and tacitly means that the boy is chubby in a quite cute way. In Instance (c), "míng huăng huăng" emphasizes the brightness of the object and describes it as extremely luminous. Thus, for the "ABB-pattern adjectives", its repetition part plays a great role in expressing more information and amplifying the effect.

(6)

a. gān jìng

dry clean

"clean"

b. gān gān jìng jìng

dry dry clean clean

"extremely clean"

(7)

a. láo dao

chat nag 
"garrulous"

b. láo lao dāo dāo

chat chat nag nag

"extremely garrulous"

Examples (6) and (7) are of similar cases. The Phrases (a) in both examples contain fewer linguistic units than the Phrases (b) do, and thus the degree described by Phrase (a) is not as high as that by Phrase (b). To specify, "gān jìng" means "clean", whereas "gān gān jìng jìng" indicates "extremely clean" by repetition. For the same reason, "láo lao dāo dāo" indicates that the person is extremely garrulous, sometime combined with the speaker's unfavorable attitude towards that person. Hence, with such a repetition, the words with more units contain comparatively more information than the original forms do.

In general, quantitative iconicity is rather explicit in words and phrases in Chinese as the repetition of words and morphemes is quite prevalent in Chinese. On the one hand, this addition of linguistic units could directly appeal to listeners' imaginative thinking and arouse their sensations in sight, hearing, taste, and touch. On the other hand, such reduplication carries the message of the speakers' personal subjective judgement. What's more, quantitative iconicity also accords with people's cognitive process as sequencing iconicity does. The more complex, important, and unpredictable a concept is, the longer it takes for listeners to process it in thinking, and thus the more units are used in language expression.

\section{Symmetric Iconicity}

Symmetric iconicity indicates that symmetric concepts correspond to their symmetric linguistic forms. As Lin (1995, p. 41) puts it, if the expressions are symmetric, then the concepts that are presented should also have symmetric relationship. In Chinese, there are many linguistic structures that manifest symmetric iconicity. For instance:

(8) Shì qíng yuè shuō yuè qīng, dào lĩ yuè biàn yuè míng.

Things more explain more clear reason more argue more justifiable.

"The more the matters are argued, the clearer the truth is."

In Example (8), symmetric iconicity is revealed through the structure of "yuè...yuè... (the more... the more ...)" as well as the antithesis of two coordinate simple sentences. For one thing, within the "yuè...yuè..." structure, its linguistic components imply a causal relationship through the use of the comparative degree. To specify, explanation would help unravel the mystery of a matter, and arguing would help justify a reason. For another, two comparative structures form a complex sentence as a whole with antithetical parallelism. That is, "shì qíng (the matter)" corresponds to "dào lǐ (reason)" as "shuō (explain)" to "biàn (argue)" and "qīng (clear)" to "míng (justifiable)". Additionally, such parallelism is considerably common in classical Chinese poetry, especially in "modern style" poetry. Rising during the Tang Dynasty, modern style poetry is marked by strict antithesis and rhyme schemes.

(9) Gōng shì gōng, sī shì sī.

Public is public private is private.

"Be scrupulous in separating public from private interests."

Sentence (9) is also expressed in a symmetric form. As symmetric iconicity suggests, the concept of "gōng (public)" indeed has symmetric relationship with "sī (private)" as they form a pair of antonyms. What's more, such a symmetric structure makes the opposition more distinct. Thus, this expression is often used to warn the incumbent to wield his right in an uninterested way. 
(10)

a. yī xīn yī yì

one heart one willingness

"whole-heartedly"

b. yī jŭ yī dòng

one act one move

"every single movement"

c. yī sī yī háo

one bit one trace

"slightest"

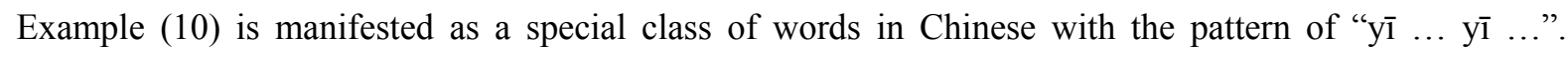
Likewise, the group of Chinese characters that could be applied to this pattern is symmetric in concept. Specifically speaking, "xīn (heart)" and "yì (willingness)" both mean one's determination and "jǔ (act)" and "dòng (move)" have almost the same denotation as movement, as well as "sī (bit)" and "háo (trace)" share the meaning of the slightest.

To sum up, symmetric iconicity implies that the symmetric relationship between the concepts would be reflected by the symmetric structure of linguistic expressions. In the Chinese language, symmetric iconicity is embodied in specific word patterns and certain sentence patterns.

\section{Asymmetric Iconicity}

Asymmetric iconicity refers to the asymmetry between topic-comment in discourse analysis as well as figure-ground in cognition. To elucidate, Tamly (2000) suggests that salient information in conceptual domain generally serves as the topic of the sentence (often in the position of a subject), while other less salient information, in most cases, acts as the comment. Further, the topic of the sentence is the figure with perceptual prominence, whereas the comment would be the ground. Asymmetric iconicity also applies to Chinese, especially in Chinese existential sentences. For examples:

(11)

a. Zì xíng chē zài wū zĩ páng biān.

Bicycle is house beside.

"The bicycle is next to the house."

*b. Wū zǐ zài zì xíng chē páng biān.

House is bicycle beside.

*“The house is next to the bicycle."

In Example (11), given that the bicycle is mobile while the house is fixed, the former tends to be more prominent in cognitive domain than the latter. In this way, the bicycle is "the figure" in cognitive operation and "the topic" in linguistic expression while the house is "the ground" and "the comment". The Sentence (a) accords with this consistency in asymmetry because "the bicycle" is placed at the position for the topic. However, Sentence (b) is pragmatically inappropriate and hardly uttered as it does not follow such consistency.

(12)

a. Qiáng shàng yǒu huā gé zǐ chuāng zǐ.

Wall has lattice window. 
"There are lattice windows on the wall."

*b. Huā gé zǐ chuāng zǐ zài qiáng shàng.

Lattice window is on wall.

*"Lattice windows are on the wall."

(13)

a. Zhuō zǐ shàng yǒu yī běn shū.

Table on has a book.

"There is a book on the table."

*b. Shū xià yǒu yī zhāng zhuō zĭ.

Book under has a table.

*"There is a table under the book."

Sentences (a) in Examples (12) and (13) represent prototypical existential sentences in Chinese. "Lattice windows" and "the book" are existential entities whereas "the wall" and "the table" are categorized into existing places. With closed contours and balanced proportions, the existential entities attract the speaker's attention more easily and thus make it a more likely candidate for "the figure" compared with the existing place. The principle is that a small and movable entity is often chosen as a figure and a big and non-movable entity is frequently chosen as a ground in cognitive operation. Therefore, in expressions, the objects should be in the position of "the topic" while the places should be that of "the comment". Sentences (a) in Examples (12) and (13) both follow such a rule, which justifies why they are considered to be prototypical. On the contrary, Sentences (b) in Examples (12) and (13) place the locations (ground) in the position of the topic, which should be for figures, hence inappropriate.

As a whole, asymmetric iconicity aptly accounts for the reason why Sentence (a) is more common whereas Sentence (b) is unacceptable in these three examples. It refers to the congruity between the asymmetry of topic-comment in linguistic expressions and figure-ground in cognitive domain. The instances show that asymmetric iconicity also applies to Chinese.

\section{Conclusion}

In conclusion, iconicity reveals the consistency among the objective world, cognition, and language. Language does not directly reflect the objective reality, but instead reflects people's cognition of the objective world. In the Chinese language, iconicity principle of language widely exists. From the level of words and phrases to the level of sentences and dialogues, iconicity could be embodied, in particular, sequencing iconicity, quantitative iconicity, symmetric iconicity, and asymmetric iconicity.

\section{References}

Givon, T. (1989). Mind code and context. New Jersey: Lawrence Erlbaum.

Givon, T. (1994). Isomorphism in the grammatical code. In R. Simone (Ed.), Iconicity in language (pp. 47-76). Amsterdam: John Benjamins.

Haiman, J. (1985). Natural syntax. Cambridge: Cambridge University Press.

Halliday, M. A. K., \& Matthiessen, C. (1999). Construing experience through meaning. London: Continuum.

Hu, Z. L. (1996). Research status of American functional linguist Givon. Contemporary Linguistics, (4), 1-10.

Lin, S. W. (1995). A brief introduction to Metaphor and iconicity. Contemporary Linguistics, (3), 40-42.

Saussure, F. (1916). Course in general linguistics. (W. Baskin, Trans.). London: Peter Owen Limited.

Shen, J. X. (1993). The study of iconicity in syntax. Foreign Language Teaching and Research, (1), 2-8+80. 
Tai, J. (1988). Verb copying in Chinese: An alternative explanation. Ms.: Ohio State University.

Tamly, L. (2000). Towards a cognitive semantics Volume (I): Concept structuring system. Cambridge, Mass: MIT Press.

Tang, Z. H. (2004). The development of adjectives in the form ABB. Journal of Shandong University (Philosophy and Social Sciences), (1), 90-93.

Wang, Y. (1990). Distinguishing features of macro structure between English and Chinese. Journal of Foreign Languages, (6), 38-42.

Wang, Y. (1999). On iconicity of linguistic symbols. Foreign Language Teaching and Research, (5), 3-5.

Wang, Y. (2003). Iconicity-dialectics view being superior to arbitrariness-fundamental view. Foreign Language Teaching and Research, (5), 3-8.

Wang, Y. (2009). On linguistic iconicity from the viewpoint of humanism in postmodernist philosophy - the 6th paper on language embodiment: Theoretical significance \& language teaching of iconicity. Foreign Language Research, (6), 32-37.

Xu, G. Z. (1988). The arbitrariness of linguistic signs. Foreign Language Teaching and Research, (3), 2-10+79.

Zhang, Z. (2004). On the types of iconicity of linguistic signs. Foreign Language and Literature Studies, (4), 16-20.

Zhang, Z. (2007). On the research of iconicity of language in China. Foreign Language Research, (1), 67-74.

Zhao, Y. F. (2000). A survey of cognitive linguistics (II). Journal of PLA University of Foreign Languages, (6), 26-30.

Zhu, Y. S. (2002). On the arbitrariness and iconicity of linguistic signs. Foreign Language Teaching and Research, (1), 2-7+80. 